\title{
Chapter 5: INDIANS IN THE COLONIAL MEDICAL SERVICE
}

\author{
[T]he Government had no option but to employ assistant and sub \\ assistant surgeons in certain parts of the colony, and that when such \\ officials had rendered meritorious service, it would appear to be \\ inequitable and indeed contrary to public interest in view of the small \\ number of European doctors, that they should be debarred from \\ continuing to practice. ${ }^{1}$
}

It is very curious that Indian doctors have been ignored in the colonial medical history of Africa. Although scholars have examined the European doctors of the various African Colonial Medical Services, non-white personnel have received comparatively little attention. ${ }^{2}$ Some studies have looked at the lower ranked African personnel, but the experiences of the Indian doctors that worked contemporaneously in higher status positions have received no attention. ${ }^{3}$ Indeed, the studies of non-European doctors in the Indian and African Empires have been so infrequent that one could be forgiven for thinking that Indians and Africans had no access to medical education and therefore were not employed in anything other than positions that did not require professional qualifications. Mark Harrison has briefly touched upon the Indian staff cohort of the Indian Medical Service (IMS) and Ryan Johnson has examined the progressive exclusion of the small numbers of black doctors from the West

\footnotetext{
${ }^{1}$ British Medical Association Archives (thereafter BMA)/B/1/162/1/10, Dominion Committee Documents, Session 1922-23, Letter from Secretary of State for the Colonies, Winston Churchill response to BMA, 10 August 1922

${ }^{2}$ Colin Baker, 'The Government Medical Service in Malawi: an Administrative History, 1891-1974', Medical History, 20,1976, pp.296-311; A. Bayoumi, The History of the Sudan Health Services, Nairobi, Kenya Literature Bureau, 1979; E.B. Van Heyningen, “Agents of Empire': The Medical Profession in the Cape Colony, 1880-1910', Medical History, 33,1989, pp.450-71; Heather Bell, Frontiers of Medicine in the AngloEgyptian Sudan, 1899-1940, Oxford, Clarendon Press, 1999; Anna Crozier, Practising Colonial Medicine: the Colonial Medical Service in East Africa, London, I.B. Tauris, 2007

${ }^{3}$ For example, C Searle, 'The Second Class Doctor and the Medical Assistant in South Africa', South African Medical Journal, 31 March 1973, pp. 509-12; Karen Shapiro, 'Doctors or Medical Aids-the Debate over the Training of Black Medical Personnel in the Rural Black Population in South Africa in the 1920s and 1930s', Journal of Southern African Studies, 13, 1987, pp.234-55; Maryinez Lyons, 'The Power to Heal: African Medical Auxiliaries in Colonial Belgian Congo and Uganda' in David Engels and Shula Marks (eds.), Contesting Colonial Hegemony: State and Society in Africa and India, London, British Academic Press, 1994, pp.202-23; Anne Digby, 'The Mid-Level Health Worker in South Africa: The In-Between Condition of the 'Middle', in Ryan Johnson and Amna Khalid (eds.), Public Health in the British Empire: Intermediaries, Subordinates, and the Practice of Public Health, New York \& London, Routledge, 2012, pp.171-92. For East Africa see John Iliffe, East African Doctors: a History of the Modern Profession, Cambridge University Press, 1998
} 
African Medical Service from the beginnings of the twentieth century. ${ }^{4}$ But these studies are exceptions, with the majority of the historiography focussing on either the white elites or the black subordinates, with little or no acknowledgement of non-white qualified practitioners. Indeed, even the broad histories of the East African medical administration written by Anne Beck in the 1960s and 1970s did not consider the work of Indians within the colonial health department. $^{5}$

This exclusion of Indians was reflected in a number of contemporary descriptions. Lord Hailey, describing the medical services of Africa in his An African Survey of 1938 also described a health structure made up principally of African subordinates, with the minority of Europeans in the leadership roles:

The medical service...can be envisaged as a pyramid, the base of which is formed by a large body of African Subordinate Staff, the apex by the fully qualified Medical Officers, and the central part by the African 'auxiliary' doctors or 'medical aids'. 6

These persistent omissions, both in historical and modern retellings, failed to recognise that by 1915 (until 1922), Indian doctors were almost double in number to the European doctors working in East African Medical Service. They omit to describe the key roles Indians had in administering British East Africa and fail to depict the multifaceted administrative reality than captured in the stereotype of a 'country of blacks ruled by blues'?

\footnotetext{
${ }^{4}$ Ryan Johnson, 'The West African Medical Staff and the Administration of Imperial Tropical Medicine, 19021914'. Journal of Imperial and Commonwealth History, 38.3, 2010, pp.419-39; Ryan Johnson, " An All White Institution": Defending Private Practice and the Formation of the West African Medical Staff', Medical History, 54.2, 2010, pp.237-54

${ }_{5}^{5}$ Beck makes passing reference to the existence of Indian medical practitioners in her book Ann Beck, A History of the British Medical Administration of East Africa: 1900-1950, Cambridge, Massachusetts, Harvard University Press, 1999 (first published, 1970), p.13. Her other works make no reference at all, see for example Ann Beck, 'Problems of British Medical Administration in East Africa between 1900-1930' Bulletin of the History of Medicine, 36,1962, pp.275-83; Ann Beck, 'Native Medical Services in British East Africa and Native Patterns of Society' in Verhandlungen des XX Internationalen Kongresses für Geschichte der Medizin, Berlin, 22-27 August 1966, Hildesheim, Georg Olms Verlagsbuchhandlung, 1968, pp.870-75;

${ }^{6}$ Lord Hailey, An African Survey: A Study of the Problems Arising in Africa South of the Sahara, Oxford University Press, 1938, p.1182

${ }^{7}$ This was, in fact, a description of the Sudan, but the stereotype held for most of British Africa. Richard Hillary, The Last Enemy, London, Macmillan and Co. Ltd., 1950, p.15
} 


\section{Set up of the Colonial Medical Department:}

Like many other legal and administrative frameworks adopted in East Africa, India provided the blueprint and the fledgling medical department of the East Africa Protectorate was directly modelled on the IMS. Just as in the IMS, it consisted of a head of the medical department, the Principal Medical Officer (PMO), European Medical Officers or Senior Medical Officers (MOs or SMOs_-dependent upon rank) as the senior staff who supervised and provided policy guidance, while Indian Assistant Surgeons and Sub-Assistant Surgeons performed the bulk of the routine medical activities. In East Africa, this core team was further helped by African medical assistants, dressers and European and non-European Nursing sisters. Additional to the Indian Assistant Surgeons and Sub-Assistant Surgeons were a small but significant cohort of Indian support staff: chiefly consisting of administrative clerks and compounders (a formulator of drugs below that of a pharmacist in status and training). ${ }^{8}$ In both of these non-qualified positions Goans had a dominant presence, in line with their reputation amongst the British for being efficient and trustworthy.

But, although strong organisational similarities existed between the two health services of the Indian and African British Empires, some crucial differences were present. For example doctors joined the IMS via a competitive examination, while the EAMS recruited its doctors on the basis of performance at interview. This led to the (by-in-large warranted) impression that the IMS was the more prestigious service, as only exceptionally gifted candidates were able to pass the difficult entrance before $1914 .{ }^{9}$ Furthermore, in East Africa all healthcare operations were centralised upon the one government medical service, while in India the IMS was the most important of three different medical services, each targeted at different sectors of the population. ${ }^{10}$ The IMS, catered principally for European patients and recruited mostly European doctors, the Central and Provincial Medical Services (CPMS) and the Subordinate Medical Service (SMS), dealt mainly with non-European patients and relied on locally

\footnotetext{
${ }^{8}$ BL/IOR L/MIL/7/14626, Collection 324A/122 Proposal for grant of pensionable status to subordinate medical staff of East Africa and Uganda Protectorates, 1915-1925; COD No.855 'Revised Rules for the Employment of Assistant Surgeons, Sub-Assistant Surgeons and Compounders in the British East Africa and Uganda Protectorates Recruited From Sources Outside the Service of the Government of India', 9 November 1917, p.1. This states that no formal qualifications were required for Compounders unlike Sub-Assistant Surgeons.

${ }^{9}$ Anna Crozier, Practising Colonial Medicine: the Colonial Medical Service in East Africa, London, I.B. Tauris, 2007, p.52

${ }^{10}$ The three operated throughout the colonial period in India, with a few amendments and additions, such as the Royal Army Medical Corps. See 'The Framework of Medicine in India', The Lancet, 16 October, 1937, p.933-5
} 
recruited Indian physicians. ${ }^{11}$ As the only medical service in East Africa, the EAMS arguably came under more focused pressure to provide comprehensive geographical healthcare coverage, as there were no alternative services supporting the majority indigenous poor.

In both the IMS and EAMS Indian doctors were an assumed component of the health personnel. Although Indian recruits were in the minority in the IMS they nevertheless were, since 1860, theoretically entitled to apply for inclusion in the government medical services on the same terms as their white peers. ${ }^{12}$ An 1880 list of the 26 successful entry candidates to IMS, for example, included 8 Indian names. ${ }^{13}$ This was quite an impressive proportion when the other circumstances that militated against Indians joining the IMS are considered. Above all, it was difficult for Indians to gain access to the financial resources to take a trip to London to participate in the IMS entrance exam. ${ }^{14}$ Furthermore, even if they achieved a position, European cultural prejudices meant that most colonials preferred not to be treated by Indians, but rather by practitioners 'of their own race'. ${ }^{15}$

In East Africa, in contrast, Indian Assistant Surgeons and Sub-Assistant Surgeons (Hospital Assistants prior to 1910) were present in the medical department as a much more obvious force since its inception. As discussed in Chapter 3, Indians were part of the medical provision in the construction of the Uganda Railway and were immediately part of the colonial medical department, which it was founded in 1895 and four IBEAC Medical Officers had their appointments transferred to the new Colonial Medical Service. ${ }^{16}$ Some of the earliest Indian medical staff included Edward Oorloff, who had joined the medical department in 1897, E.W. Rodrigo and G.P. Vinod who commenced their employment in

\footnotetext{
${ }^{11}$ M.S. Rao, 'The History of Medicine in India and Burma', Medical History, 12.1, 1968, pp.52-61, p.56; D.G. Crawford, A History of the Indian Medical Service, 1600-1913 (two vols.), London, W. Thacker, 1914, p.649; Mark Harrison, Public Health in British India: Anglo Indian Preventative Medicine, 1859-1914, Cambridge University Press, 1994, p.32

12 'Exclusion of Natives of India From the Army Medical Service', The Times, 25 February 1861, p.5; Also see Roger Jeffery, 'Recognising India's Doctors: The Institutionalisation of Medical dependency, 1918-1939', Modern Asian Studies, 13.2, 1979, pp.301-26, p.304

13 'Indian Medical Service', The Times, 24 August 1880, p.3

${ }^{14}$ For the campaigns to improve Indian access to the IMS see: Roger Jeffery, 'Doctors and Congress: The Role of Medical Men and Medical Politics in Indian Nationalism', in Mike Shepperdson and Colin Simmons (eds.), The Indian National Congress and the Political Economy of India, 1885-1985, Aldershot, Brookfield, USA, Avebury, 1988, pp.160-73

15 'The Framework of Medicine in India', The Lancet, 16 October, 1937, p.933-5, p.934

${ }^{16}$ The first four European doctors were Dr A.D. Mackinnon, Dr W.H. MacDonald, Dr J.S. MacPherson, Dr R.U. Moffat. See Arthur Dawson Milne, 'The Rise of the Colonial Medical Service', Kenya and East African Medical Journal, 5, 1928-9, pp.50-8, p.53
} 
1898 and Maula Buksh who joined the department in $1899 .{ }^{17}$ It was apparent from very early on that, even if the healthcare focus was primarily on the needs of the European community, insufficient numbers of European doctors were available and the department needed supplementary staffing. ${ }^{18}$ This shortage was to become even more apparent when military campaigns also intervened to take Medical Officers away from their official posts. Between 1897-1900 the military 'struggle in the North', for example, was said to have consumed all the available European medical personnel. ${ }^{19}$ Furthermore, as Crozier has pointed out, the East African Colonial Medical Service was by no means a popular career and the service had its own recruitment difficulties. The job, although attractive to some, was nevertheless perceived as something of a last resort for the newly qualified British doctor. Pay, although stable, was low and working conditions were perceived as being both inadequate and uncongenial. ${ }^{20}$ Given the relative unpopularity of a medical career in Africa the inclusion of Indian doctors in the Colonial Medical Service was a natural and explicable way of compensating for staff shortfalls at a lower cost.

Correspondence between Kenya, London and India confirms a heavy dependence on Indian staff for the provision of medical services between 1891 and 1922. A letter from the PMO in January 1907 urged the Colonial Office and the India Office for stronger action to secure Indian medical staff. ${ }^{21}$ The concerns voiced were quite commonplace for the time:

Having regard to difficulty of procuring Hospital Subordinates for the Medical Department of East Africa and Uganda through Agent General in India I have the honour to suggest that the Colonial Office be requested to open negotiations with the Government of India to obtain loan of Assistant Surgeons and Hospital Assistants for service in East Africa and Uganda. There are at present two vacancies for Assistant Surgeons and two for Hospital Assistants, and after April

\footnotetext{
${ }^{17}$ BL/Microfilm/Government Publications Relating to Kenya, 1897-1963, East African Protectorate Blue Book, 1901/1902

${ }^{18}$ H.A. Bödeker, 'Some Sidelights on Early Medical History in East Africa', The East African Medical Journal, 12, 1935-36, pp.100-7, p.101; p105

${ }^{19}$ Arthur Dawson Milne, 'The Rise of the Colonial Medical Service', Kenya and East African Medical Journal, 5, 1928-9, pp.50-8, p.53

${ }^{20}$ Anna Crozier, Practising Colonial Medicine: the Colonial Medical Service in East Africa, London, I.B. Tauris, 2007, p.95

${ }^{21}$ BL/IOR/ MIL/7/14471,1907-1909, Collection 323/49 Medical Subordinates for Service in East Africa and Uganda, letter from Dr. Will, Principal Medical Officer, 28 January 1907
} 
next there will be vacancies for five additional Hospital Assistants who should arrive as soon after that date as possible. ${ }^{22}$

There were further telex exchanges spelling out the urgent need to negotiate a loan of subordinate medical staff from India, throughout $1907 .{ }^{23}$ In general the India Office's reluctance to quickly comply was a cause of agitation amongst East African colonial administrators. Reminders were frequently sent to India emphasising the urgency of requests and stipulating that experienced, qualified and higher grade Indian Hospital Assistants were required.

The same themes can be discerned in earlier and subsequent years. The 1908 Annual Medical Report highlighted the shortage of Indian subordinate medical staff; bluntly stating 'as usual there was great difficulty in keeping staff to required numbers. ${ }^{24}$ In the same report, the PMO praised the work of the Assistant and Sub-Assistant Surgeons and postulated that the lack of Indian candidates offering their services in Kenya was because 'pay and prospects offered are insufficient ${ }^{, 25}$ Indeed until 1922 this leitmotiv continued to run throughout the correspondence and Annual Medical Reports of Medical Officers Mackinnon, Moffat, Will and Milne. In 1895 Mackinnon had made a special request for the extra recruitment of 'very capable men for the ordinary diseases of these countries' and Milne recollected that during this period, when the medical department was just getting on its feet, that many Indian Surgeons and Sub-Assistant surgeons had devoted 'faithful service' to the cause. ${ }^{26}$ In 1921 , even John Langton Gilks, the PMO who was to actively squeeze Indians out of the Colonial Medical Service employment, had remarked that there were insufficient numbers of Indian medical staff in his first year at the headship of the medical department. ${ }^{27}$ At one stage the shortage of subordinate staff from India was considered so serious that the Colonial Office considered starting a recruitment drive in other colonial dependencies, such as Egypt, although a lack of appropriately qualified doctors available for export meant that these efforts

\footnotetext{
22 BL/IOR/ MIL/7/14471,1907-1909, Collection 323/49 Medical Subordinates for Service in East Africa and Uganda, letter from Dr Will, Principal Medical Officer, 28 January 1907

${ }^{23}$ BL/IOR/ MIL/7/14471,1907-1909, Collection 323/49 Medical Subordinates for Service in East Africa and Uganda, letter from India Office, 29 March 1907, letter from Colonial Office, 5 July 1907, letter from Colonial Office, 11 September 1907, letter from Colonial Office, 25 September, Letter from Military Department, India Office, 26 October 1907

${ }^{24}$ NA/CO/544/1 Administration Reports 1903-1909, Annual Medical Report, 1908, p.3

${ }^{25}$ NA/CO/544/1 Administration Reports 1903-1909, Annual Medical Report, 1908, p.3

${ }^{26}$ BL/IOR/MIL/7/2175 A.D. Mackinnon to Mr. Jackson, 13 April 1895; Arthur Dawson Milne, 'The Rise of the Colonial Medical Service', Kenya and East African Medical Journal, 5, 1928-9, pp.50-8, p.58

27 Annual Medical Report, 1921, p.21
} 
were unsuccessful. ${ }^{28}$ Worries about adequate numbers were further compounded by concerns that the quality of candidates despatched for service in Kenya was not so high. Particularly, there was concern that India was reserving the best candidates for work in its own country, and only offering the lower quality staff for overseas service. ${ }^{29}$

The idea to recruit medical assistants from India was also stimulated by the fact that no equivalently trained medical workforce existed within East Africa at that time. Whereas the medical training of Indians in western medicine had been underway since the first third of the nineteenth century, this was not the case for East Africans where access to even a rudimentary medical training did not begin until 1917 (at Mengo Hospital, Uganda). In 1923 a six-year training course for Senior African Medical Assistants was initiated at Makerere training centre (later University), but it was to take until 1931 for African doctors to graduate from this institution. Even then, these doctors although licenced to work for the government medical department, were denied the right to practice privately, even if they were to stop working for the government medical department. Indeed, this privilege that was not granted to African doctors until 1950, and then only after they had first undertaken a satisfactory period of employment in government service. ${ }^{30}$ In Kenya the training of African staff was regarded as much more difficult than in Uganda because of the lack of Kenyan recruits who had received a secondary school education.

\section{Terms and Conditions of Employment:}

It is not known when the first formal regulations concerning the employment of Indian subordinate medical staff in East Africa Protectorate and Uganda were produced. Regrettably no copy of this document can be found. Instead, the earliest set of employment regulations that have been located derive from 1917, presumably tightening up the criteria and contractual obligations that were outlined in the original guide. ${ }^{31}$ Even though we cannot

\footnotetext{
${ }^{28}$ BL/IOR L/MIL/7/2188 Collection 48/35 Hospital Assistants for Uganda Railway and Uganda, Foreign Office letter 23 January 1897

${ }^{29}$ Ann Beck, A History of the British Medical Administration of East Africa, 1900-1950, Cambridge, Mass., Harvard University Press, 1970 p.13

${ }^{30}$ Lord Hailey, An African Survey: A Study of the Problems Arising in Africa South of the Sahara Revised 1956, London, New York, Toronto, Oxford University Press, 1957, p.1081; For more detail on the history of African medical education in East Africa see John Iliffe, East African Doctors: a History of the Modern Profession, Cambridge University Press, 1998

${ }^{31}$ BL/IOR/L/MIL/7/14626, Collection 324A/122 1915-25, Proposal for Grant of Pensionable Status to Subordinate Medical staff of East Africa and Uganda Protectorates, COD No.855 'Revised Rules for the Employment of Assistant Surgeons, Sub-Assistant Surgeons and Compounders in the British East Africa and
} 
have the benefit of seeing the original guidelines, the 1917 terms and conditions nevertheless provide an important overview of policies and staffing preferences with regards to Indian medical recruitment. It seems reasonable to suggest that the most of the views expressed within this document were ones that had been de facto adhered to since the beginnings of the government medical department:

\section{Qualifications.}

(a) Good character, physique, qualified in English.

(b) Religion, immaterial

(c) Assistant Surgeons must possess a University Degree or Medical Diploma.

(d) Sub-Assistant surgeons must possess Certificates of Competency from recognised Indian colleges and schools, list of which to be kept and supplied to the Agents in Bombay.

\section{Period of Engagement.}

Three years from the day on which the employee lands at Mombasa until the day of his departure therefrom on his return to India. This term is subject to extension owing to exigencies of the service.

4. Pay.

(1) Assistant Surgeons Rs. 250/- per month rising to Rs. 300/- per month by annual increments of Rs. 25/- per month.

(2) Sub-Assistant Surgeons

(a) Senior Sub-Assistant Surgeons Rs. 220/- per month rising to

Rs. 240/- per month by annual increments of Rs. 10/- per month.

(b) Sub-Assistant Surgeons Rs. 200/- per month by annual increments of Rs. 10/- per month.

(3) Compounders Rs. 75/- per month by annual increments of Rs.

$5 /-$ per month....

\section{Quarters.}

Government quarters free of rent but not of rates and taxes or other similar outgoings when available but when no such quarters are 
available no allowance in lieu will be granted. When free quarters are enjoyed the value of the quarters is not reckoned as part of the pensionable emoluments of the post. ${ }^{32}$

Additional stipulations were made with regards to conditions for leave, passages and pensions. Leave was to be three months on half pay after 33 months of continuous service or five months on half pay after 43 months continuous service. Second class sea passage was paid between India and Mombasa for both Assistant Surgeons and Sub-Assistant surgeons: although this allowance was not extended for any accompanying family. All posts of Assistant Surgeons and Sub-Assistant Surgeons were in principle pensionable. However Indian holders of the posts were considered to be on probation for three years and were only eligible for pension benefits thereafter if their work was passed as being considered satisfactory by the PMO. Finally, it was written into their contracts that all Indian medical personnel had to be available for military duty at the discretion of the PMO, despite their employment in the civil medical department (unsurprisingly, despite this clause, no provision for injury pensions were made in their contracts). ${ }^{33}$

As would be expected, these conditions of employment were much less favourable than those offered to European Medical Officers. Nonetheless that fact that they were formalised offers further contributory evidence that Indian staff were regarded as an integral part of the colonial medical department and, at least in 1917, were anticipated as remaining so. The vagueness of some of the recruitment stipulations, however, is nonetheless quite striking. The specific qualifications needed for entry into the service, for example, were only imprecisely addressed in the 1917 guide, with no mention made of the specific medical degrees that doctors were expected to have achieved. As the quotation above shows, in 1917 Assistant Surgeons were required to have achieved a 'university degree or medical diploma', while Sub-Assistant Surgeons needed to have 'a certificate of competency'. As this was at a period

\footnotetext{
${ }^{32}$ BL/IOR/L/MIL/7/14626, Collection 324A/122 1915-25, Proposal for Grant of Pensionable Status to Subordinate Medical staff of East Africa and Uganda Protectorates, COD No.855 'Revised Rules for the Employment of Assistant Surgeons, Sub-Assistant Surgeons and Compounders in the British East Africa and Uganda Protectorates Recruited From Sources Outside the Service of the Government of India', 9 November 1917

${ }^{33}$ BL/IOR/L/MIL/7/14626, Collection 324A/122 1915-25, Proposal for Grant of Pensionable Status to Subordinate Medical staff of East Africa and Uganda Protectorates, COD No.855 'Revised Rules for the Employment of Assistant Surgeons, Sub-Assistant Surgeons and Compounders in the British East Africa and Uganda Protectorates Recruited From Sources Outside the Service of the Government of India', 9 November 1917
} 
when several Indian medical colleges offered medical degrees recognised in the UK, it is possible that the criteria were kept deliberately vague as a means of giving the PMO some leeway and room for personal discretion when granting appointments. Certainly in the very early years of the colonial medical establishment occasionally individuals were taken on without having achieved medical qualifications. There were exceptional instances of a compounder being promoted to the rank of a Sub-Assistant surgeon (for example, the case of S.F. Da Costa ). ${ }^{34}$ Whatever the reason to not be too specific about entry requirements was, some reticence to make minimum qualifications too specific was in evidence. In fact, qualifications to be an Assistant or Sub-Assistant Surgeon were not actually formally specified in the Medical Practitioners Registration Ordinance of 1910 and left the decision in the hand of the PMO. Before that point, the declared recruitment standards of the colonial medical department were even more inexplicit; namely, to seek 'experienced and fully qualified' individuals from specific Indian schools that had high entry standards rejecting those of inferior education, such as 'class 4' subordinates. ${ }^{35}$ In reality Assistant Surgeons were expected to possess a university degree or diploma and Sub-Assistant surgeons a certificate from recognised Indian colleges or schools. The 1917 guidelines merely formalised the entrance qualifications that had existed. Under these new terms, the minimum qualification for an Assistant Surgeon was a medical diploma, or Licentiateship, which was achieved after a minimum of three years medical training in India

More significantly the racial climate of the time, indeed right up until independence, meant that even Indians doctors who had achieved higher than this stipulated minimum and had equivalent qualifications and experience to their European colleagues were unable to become full Medical Officers at equivalent salaries. The unfairness of this became particularly apparent as the twentieth century progressed and an increasing number of medical students in India took the MBBS degree, which was -theoretically at least-regarded on parity with the General Medical Council (GMC) approved MBBS that could be taken in the UK. ${ }^{36}$ It is evident that some extremely experienced and well-regarded Indians practised medicine at the Assistant or Sub-Assistant Surgeon level despite having qualifications equal to their senior

\footnotetext{
${ }^{34}$ Annual Medical Report, 1914, Promotions, p.11

${ }^{35} \mathrm{BL} / \mathrm{IOR} / \mathrm{L} / \mathrm{MIL} / 7 / 14441: 1898-1901$ Collection 323/19 Medical subordinates for Uganda Railway: Extension of Service and Replacement, F. Ranson letter 21 June 1900; BL/IOR/L/MIL/7/14471 1907-1909, Collection 323/49 Medical Subordinates for Service in East Africa and Uganda, Colonial Office note 4 November 1907 ${ }^{36} \mathrm{KNA} / \mathrm{MOH} / 1 / 716$, Appointment of Government Asian Doctors, Memo from Director of Medical Services, 11 January 1955; See also NA/CO/822/107/22 1942-43, Conditions of Service: Non-Europeans Appointed to Posts Ordinarily Assigned to Europeans; NA/CO/822/34/8 Governor's note to Colonial Office 23 July 1931
} 
European counterparts. This was evidently not palatable to all. Dr A.C. L.de Sousa, for example (who subsequently became a well-known general practitioner and public figure) resigned from Government service specifically because of lack of career prospects for him to be promoted. ${ }^{37}$ Dr Nair, who worked in Kenya between c.1918 and c. 1928 , provides another example. Despite the fact that he travelled to the UK and obtained the qualifications of LM (Dublin) and DTM (1920), he found to his frustration that he could never be promoted beyond the grade of Assistant surgeon. ${ }^{38}$ Similarly, Dr Bakhtawar Singh, who had qualified with the GMC recognised MBBS degree from Punjab University (Lahore) in 1929, worked for several years in the Kenya Medical Department as an Assistant Surgeon with no prospect for promotion despite the fact his degree was at the same level as that possessed by his European superiors. $^{39}$

The issues of remuneration, inequality of status compared to Europeans and limited prospects for advancement were persistent bones of contention for the Indian doctors throughout the colonial period, but of all of their contractual terms, perhaps issues of pay were the most persistently debated. Although Indians working in East Africa governmental service received more than they would have working in the CPMS and SMS, the debates over the inadequate remuneration of Indian doctors in East Africa mirrored the long history of the pay issue for native doctors in India, where salaries were also felt to be problematically low. ${ }^{40}$ Notably however, the Colonial Service was thought of as poorly paid by Europeans as well as by Indians, although of course European Medical Officers were in a much better financial position than their Indian counterparts. While both groups had their passage to East Africa paid (albeit in different classes), the salaries offered were far from equivalent. While European Medical Officers were paid $£ 400$ per annum (in 1939 this changed to $£ 600$ per annum), the salary of the Assistant Surgeon was approximately $£ 200$ and that of SubAssistant Surgeon was under $£ 70 .{ }^{41}$ Furthermore, unlike the European doctors, who were

\footnotetext{
${ }^{37}$ RHL/Papers Collected by H. Topiwala Related to Indian Doctors in Kenya, expected deposit date 2015, $\mathrm{Dr}$ A.C.L de Souza, In Memorium, Nairobi, Majestic Printing Works, 1958, p.10; p.28

38 'Dr Nair back from England', East African Chronicle, 16 October 1920, p.18; 'Dr T.D. Nair promoted' East African Chronicle, 27 November 1920, p.11

${ }^{39}$ RHL/Papers Collected by H. Topiwala Related to Indian Doctors in Kenya, expected deposit date 2015, Manmeet Singh, The Life and Times of late Dr Bakhtawar Singh, $6^{\text {th }}$ May 2008

${ }^{40}$ Indian Sub- Assistant Surgeon, The Lancet, 19 October 1867, pp.503-4; BL/IOR/L/MIL/7/19041, Note by R.H. Charles 2 September 1921; BL/IORL/MIL/7/14626, Coryndon letter dated 1 April 1921 [recommends improving the pay of Sub-Assistant Surgeons to stimulate recruitment].

${ }^{41}$ BL/IOR/MIL/7/2175:1895, Collection 48/23 East Africa Protectorate: Raising of Indian Contingent of 300 men for Mombasa, Memo to Lord Hamilton, Secretary of State, 11 March 1896; John Iliffe states that Medical Officers got two or three times higher pay than Assistant surgeons. John Iliffe, East African Doctors: a History
} 
provided with government housing, subordinate Indian staff had neither accommodation allowance nor guaranteed government housing, no gratuity for long service, no passages paid for spouses and family, and no formal provision was made for their pension, unless they first passed a three-year probationary period. ${ }^{42}$

The lowness of the salary combined with the difficulty of the job in an unfamiliar climate, meant that there were persistently severe recruitment problems between 1897 and 1922. Consequently, the issue of revising the pay of Indian doctors in East Africa was the subject of debates lasting many years between Whitehall, the Protectorate and the Government of India. The first small improvement to one element of the pay package was finally made in October 1915 when the Secretary of State, Bonar Law, approved a recommendation to grant pension rights to all Subordinate Surgeons employed in East Africa subject to the Governor retaining a right of refusal. Although initially Bonar Law's recommendations only applied to staff on secondment from India, by 1921 all posts of the subordinate medical staff of the protectorate became eligible for a pension. ${ }^{43}$

More substantive and major revisions to pay were not made until 1924, by which time other polices had intervened in Kenya to discourage the employment of Indians. The fact that the change in policy took so long to emerge was partially to do with political nervousness over angering the powerful Kenyan settler society, who was concerned that if the job was too attractive that too many Indians would immigrate to East Africa. Indians had earlier expressed their frustration, with the East African Chronicle commenting in 1920: 'A fair minded observer would admit that if a non-European subordinate service is not up to the mark the root defect lies in the salary and conditions offered, and not in the personnel. ${ }^{44} \mathrm{Sir}$ Robert Coryndon, Governor of Uganda had noticed the difficulty of 'filling vacancies at lower rate of pay' and been lobbying London to increase the starting level of salary by 20 -

of the Modern Profession, Cambridge University Press, 1998, p.78. For European Medical Officer salaries see Anna Crozier, Practising Colonial Medicine: the Colonial Medical Service in East Africa, London, I.B. Tauris, 2007, pp.27-8

${ }^{42}$ BL/IOR/L/MIL/7/14626 Collection 324A/122 1915-1925 Proposal for Grant of Pensionable Status to Subordinate Medical Staff of East Africa and Uganda Protectorates, COD No 855: Revised Rules for the Employment of Assistant Surgeons and Compounders in the British East Africa and Uganda Protectorates Recruited from Sources Outside of the Service of the Government of India, 9 November 1917

${ }^{43}$ BL/IOR/L/MIL/7/14626 Collection 324A/122 1915-25 Proposal for Grant of Pensionable Status to Subordinate Medical staff of East Africa and Uganda Protectorates, Bonar Law letter, 28 October 1915; Robert Coryndon, letter, 1 April 1921

44 'New Kenya Civil Service Scales: Comparison between Asian and European Emoluments', East African Chronicle, 4 September 1920, p.12 
25\% for Indian Assistant and Sub-Assistant Surgeons in the region since 1921, but his suggestions were met with resistance for these reasons in Kenya. ${ }^{45}$ It took until the ascension of the Labour MP, J.H. Thomas to the position of Secretary of State for the Colonies for the new pay structure to finally gain approval in 1924. This stipulated that Assistant Surgeons should receive an annual pay of $£ 360-£ 420$, £300-£360 for Senior Sub-Assistant and $£ 200$ $£ 240$ pounds for Sub-Assistant Surgeons. In contrast, by 1939, the pay of the European doctor improved significantly. ${ }^{46}$ The 1924 decision to modify the pay structure of the Indian doctor therefore should be seen as a relatively minor improvement, particularly in Kenya where the rank of Senior Sub-Assistant Surgeon was simultaneously removed. A marginal improvement, furthermore, which confirmed the political reality of an entrenched policy to maintain major salary differentials based on race. Stimulated by the fear of possible legal challenges from the League of Nations, the differences in salaries and terms of employment between Indian and European professionals were finally published as a set of rules in 1947. Although these rules carefully made no explicit reference to race determining salary, the wording of the document was such that it, in effect, it allowed for the continuation of a situation that has been in existence for several decades. ${ }^{47}$

Additional to the complaints about the level of the core salary were complaints about the extent to which Indian doctors were dependent on the personal discretion of the senior colonial administrators in Kenya. The PMO and the Governor retained overwhelming power in the interpretations of all the regulations regarding remuneration. For example, in 1918 the Governor's Executive Council reviewed and granted War bonuses to five Assistant Surgeons who supposedly 'look and behave as English Gentlemen'. ${ }^{48}$ The Executive Council minutes of the 1916 reveal that the Council concerned itself over individual dismissals as well as on the allocation of perks, such as additional allowances, including horses to travel or the right to train tickets. ${ }^{49}$ Overall this system was felt to be too subjective and too dependent upon the personal good will of the PMO.

\footnotetext{
${ }^{45}$ BL/IOR/L/MIL/7/ Collection 324A/122 1915-1925 Proposal for Grant of Pensionable Status to Subordinate Medical Staff of East Africa and Uganda Protectorates, letter from Robert Coryndon, 1 April 1921

${ }^{46}$ Anna Crozier, Practising Colonial Medicine: the Colonial Medical Service in East Africa, London, I.B.

Tauris, 2007, p.27

${ }^{47} \mathrm{NA} / \mathrm{CO} / 822 / 34 / 8$ Appointment of Indian men and Women to Higher Grade Posts, Governor's note to Colonial Office, 23 July 1931; NA/CO/822/284 Salaries in Relation to Race and Domicile, 1951-1953, Note of E.L. Scott, 27 June 1951

${ }^{48} \mathrm{NA} / \mathrm{CO} / 544 / 14$ 1916-1922, Executive Council Minutes, 1918, p.363

${ }^{49}$ NA/CO/544/14 1916-1922, Executive Council Minutes (Confidential), 1916, p.42; p.109
} 
Amongst the additional benefits, it was restrictive access to the right to private practice which caused the most upset. Again, debates about this were not confined to the Indian subordinates and access to private practice was a notoriously contentious issue amongst European Medical Officers. In general, however, although government policy was never quite explicit about its formal policy on this, most European MOs were allowed to practice privately so long as it did not interfere with their government work. ${ }^{50}$ With regards to Indian doctors the debates around private practice were similarly ambiguous. In Uganda, for example, it was decided that 'it would not be possible to deprive' the much lower paid Indian medical staff of privileges which Europeans were permitted to retain. ${ }^{51}$ The situation in Kenya was different because the country contained more resident general practitioners, who did not want the competition. The engagement of Government doctors in private practice was fiercely resisted by European general practitioners and became a contentious issue in Kenya. ${ }^{52}$ Resentments towards this policy were also evident among Indian members of the colonial medical department (see Chapter Seven).

The Medical Department placed a very high premium on the obedience of the Indian doctor to his European superiors. There was a process for appeal and complaints - although because of the prevailing ideological commitments to ideas about race-in practice Indians had very little chance of instituting change. Individual petitions seeking readdress from alleged unfair treatment by members of the Medical Department could be made to the Governor or the Colonial Office in London. It seems that despite the low odds in gaining a fair hearing, Indian doctors had enough faith in the system to submit numerous petitions via this route.

Unsurprisingly, perhaps because of the PMOs membership of the Governor's Executive Council, almost all the appeals and petitions submitted by Indians were unsuccessful. A few examples in East Africa provide an indication of grievances. For example, in 1926 Dewan Chand, a Sub-Assistant Surgeon, appealed against a decision to reduce his salary by $10 \%$ because of perceived disloyalty and insubordination. He was described as having performed

\footnotetext{
${ }^{50}$ Anna Crozier, Practising Colonial Medicine: the Colonial Medical Service in East Africa, London, I.B. Tauris, 2007, p.30

${ }^{51}$ NA/CO/822/38/4 1930-1938, East African Medical Service Regulations: Private Practice, letter, Governor Gowers to Secretary of State, 10 July 1931

52 BMA/B/162/1/9, Dominions Committee: 1921-22, Meeting 30 June 1922, p.3; See also see Annual Medical Report, 1919, p.19 which mentions government paying full time salaries to Medical Officers whose work, to a large part, consists in the treatment of private patients; debate in the press spoke explicitly about the threat that Indian doctors posed to European private practitioners if they engaged in private practice on the side. See: 'Licensing Indian Doctors', The Leader [supplement], 25 March 1922, p.4; more generally: 'Geddes Considerations', The Leader, 22 April 1922, p.14 stated that government doctors (presumably both European and Indian) had 'practically wiped out' the private practitioner in the provinces and outstations.
} 
his duties diligently but 'not with fidelity'. ${ }^{53}$ Another example was the petition by Sant Ram in 1932 against a decision to dismiss him from service, when he claimed that his employment had been terminated because of an unjustified personal bias against him. ${ }^{54}$ Similarly in 1935 Dr A.V.R. Rao pleaded a case for the supplementary discretionary payment for meritorious service for retired assistant and Sub-Assistant Surgeons. His petition was against the decision of the PMO not to grant the award and the appeal was rejected. ${ }^{55}$

It is clear from the evidence that remains that Indians were far from unquestioning about the restrictions placed upon them and that they were often indignant about the terms under which they were employed. In some senses, this was a normal response to working in any department of the British Colonial Service where pay and conditions were commonly felt to be inadequate. European Medical Officers, also regularly complained about their poor salaries, lack of access to decent facilities and their annoyance towards the extensive bureaucracy. A big difference, however, is that while the European MOs enjoyed the support of the local branch of the BMA and the PMO to lobby the Colonial Office for improvements, the Indian cause was not championed by this medical representative body in the same way. Indeed, quite the reverse was true. ${ }^{56}$ The BMA's lack of support for pursuing similar reforms for the Indian doctors who possessed recognised qualifications was partly a result of the fact that Indians at this time were banned from membership of this professional body, but also offers a powerful example of how ingrained racial distinctions were when making assessments of professional equitability.

Despite the fact that Indians were regularly included on the medical staff, and were even praised for their contributions before 1922, nearly every positive remark made about Indians was made in a climate that concurrently also assumed that they were neither as able nor as desirable as European doctors. These profound presumptions - particularly in evidence in the

\footnotetext{
${ }^{53}$ NA/CO/691/89/9 1926-1927, Dewan Chand, Sub-Assistant Surgeon: Medical Retirement; Gratuity Award, letter from Governor to L. Amery, 31 January 1927, p.4; p.7

${ }_{54}$ NA/CO/691/123/15 Petition about retrenchment by Sant Ram, former Sub-Assistant Surgeon, Medical Department, 1 January 1932-31 December 1932, letter, Governor to Secretary of State 18 June 1932

${ }^{55}$ NA/CO/536/184/5 1935, Dr A V S Rao, Former Sub-Assistant Surgeon, Medical Department: Petition Submitted in Regard to his Dismissal from Post, and Applying for the Grant of a Licence to Practice again in Uganda, 28 August 1935-30 November 1935

${ }^{56}$ BMA/B/162/1/12, Dominions Committee Meeting, Memorandum on the Medical and Sanitary Services of Kenya from BMA Kenya Branch, 6 March 1925, p.3
} 
highly racially charged environment of settler-dominated Kenya-hampered Indian claims for equal treatment in all realms of government service, whether in terms of receiving an equitable salary, or in terms of serving at an equivalent rank to Europeans. When, for example, in 1931, Mohamed Asan (a railway worker), appealed against the fact that his promotion within the Railway department was turned down, it was noted on the file that 'no qualification, merit or efficiency' would enable an Asian to rise from a subordinate to a higher position. ${ }^{57}$ Going further Colonial Office exchanges on the same file of 1931 went on to state:

In East Africa the conditions of service for persons of different races vary as regards leave, pensions, etc., largely on account of the varying effects of climate on persons of different races. Theoretically there is no reason why a suitable Indian or African should not rise to a high appointment, but in practice this would obviously give us rise to considerable difficulty... In practice appointments filled by Asians have so far been of subordinate nature...there is no racial discrimination in the selection of candidates for any appointment. ${ }^{58}$

Officially at least the justification for restricting the appointment or advancement of Indian medical staff typically centred on the lack of suitable applicants, but the evidence reveals more fundamental prejudices. For example, some Indians tried to enter the Colonial Medical service via the normal recruitment routes of selection via interview in London, hoping no doubt that this would be a means of being appointed to the superior rank of Medical Officer. The reaction to these applications by the Director of Colonial Service Recruitment, Ralph Furse is illustrative: '[i]n dealing with Indian applicants our method so far had been to do all we can to avoid telling them openly that they are ineligible on racial grounds.' Rather brutally the this memo describes how the Colonial Office in London would allow Indians to fill in all the application forms for a position as a Medical Officer and then should find 'some excuse or other' to turn them down. ${ }^{59}$ Consequently, when P.L. Gupta (MB, ChB, DPH, FRCS) from Gwalier State, India enquired via letter in 1923 whether there were any

\footnotetext{
${ }^{57} \mathrm{NA} / \mathrm{CO} / 822 / 34 / 8$ Appointment of Indian Men and Women to Higher Grade Posts, Colonial Office note, 16 January 1931 [here the complaints of the Indian Overseas Association are discussed]

${ }^{58} \mathrm{NA} / \mathrm{CO} / 822 / 34 / 8$ Appointment of Indian Men and Women to Higher Grade Posts, Colonial Office note, 16 January 1931

${ }^{59}$ NA/CO/877/1/43122 Minute: Furse, Method of Dealing with Applications for Colonial Employment on the Part of Natives of India', 29 August 1921
} 
vacancies suitable for him either in the West or East African Colonial Medical Service, the Colonial officials decided that 'any such appointment would be undesirable'. However, it was minuted that Gupta should not be explicitly rejected on racial grounds. Clearly it was preferable that the Colonial Office should pursue a quiet policy of refusal, without making any open declarations over racial ineligibility. ${ }^{60} \mathrm{~A}$ similar note in a colonial office reiterates the persistence of this informal policy. In 1931 Governor of Kenya defended the way this recruitment policy was subtly managed in the Colonial Administrative Service in a letter to a senior official in the Colonial Office:

If all European posts were thrown open to Asians I should hesitate to contemplate the results. Let us imagine a situation where the Administrative Officer in charge was an Indian and the MO was a European. The difficulty would be insurmountable...the idea of throwing the Administrative service open is quite impracticable. It is not colour of a man's skin but whether he can command the respect of both his European and African subordinates. I cannot conceive any Indian being able to survive the test in Kenya, whatever his qualifications. $^{61}$

Finally, another supplementary argument sometimes put forward for the lesser suitability of Indian doctors: namely, it was claimed that Indians were inherently unsuited to treating African patients because they simply could not command their respect in the same way as Europeans could. Such views were enduring. One memo of 1951 asserted that Indian doctors did not have 'the qualities for exercising control and discipline over the African staff.' The same document also went on to describe the way that 'Africans would undoubtedly resent the Indians' if they had to come under their medical care. ${ }^{62}$

This state of affairs continued in Kenya throughout the colonial period. It was felt that few Indians could never 'either clinically or administratively' prove equivalent to Europeans. ${ }^{63} \mathrm{It}$ was only as late as 1955, that the Medical Department in Kenya created a new grade entitled

\footnotetext{
${ }^{60}$ NA/CO/877/1/43122 Minutes: 'Applications by Natives of India for Appointments in the Colonial Service', $5^{\text {th }}$ October 1921, Discussion of Letter by PL Gupta, 17 August 1923.

${ }^{61}$ NA/CO 822/34/8 1931, Note to Bottomley, 16 January 1931

${ }^{62}$ NA/CO 822/284, 1951-3 Note, E.L. Scott, Salaries in Relation to Race and Domicile, 27 June 1951

${ }^{63} \mathrm{KNA} / \mathrm{MOH} / 1 / 716$, Appointment of Asian Medical Officers, Memo 11 January 1955 (also confirms that the salary of each Asian was based on 3/5ths of that which a European received- colloquially known as 'the $3 / 5$ th rule').
} 
Assistant Medical Officer for Indians. This was meant as a salve to ease discrepancies, but in fact the creation of a separate job grade (and one moreover that was still subordinate to Europeans) only served to further reveal how deeply unwilling officials were to make Indian doctors of equal pay and status to their European colleagues. ${ }^{64}$

\section{Distribution and Numbers:}

Several sources of information can be utilised to make an assessment of the number of Indian doctors who were engaged in Government Medical Department. These include the Blue Book, the Medical Register in the Official Gazette (from 1910), The Annual Medical Reports (from 1911) and the Medical Directory. Unfortunately all of these sources have shortcomings because of their lack of consistent availability over the entire period that this study covers. They also, when crosschecked have been found not be consistent with each other and to variously contain differing definitions of medical staff over time. However a reasonable assessment of the numerical strength of the doctors can be made using the staff numbers listed in the Blue Book until 1910 and in the Annual Medical Reports between 1911-37. As detailed in Appendix 2, Indians were an important part of the medical staff until the early 1920s, peaking in around 1919/1920 at 72 staff.

In Simpson's 1914 report he outlined the regional distribution of staff. His results showed the way that European doctors were, as frequently as possible, located in urban areas and how Indian doctors were sent to, the less favourably regarded, remote outposts such as Nyanza and Kenia. This decision to use Indian doctors to provide healthcare in 'more remote' areas was part of a very deliberate staffing policy whereby Europeans were preferably located in the 'centres of European population' s and 'provincial head quarters' such as Nakuru and Eldoret. $^{65}$

With an average ratio of 1 European MO for 200,000 people, the typical rural African had little prospect of receiving treatment from a European doctor but would have been more likely treated by an Indian. However, even then, given the large indigenous African population the coverage provided by Indian doctors was skeletal and barely adequate. Some

\footnotetext{
${ }^{64} \mathrm{KNA} / \mathrm{MOH} / 1 / 716$, Appointment of Asian Medical Officers, Memo 11 January 1955

${ }^{65}$ Annual Medical Report, 1921 p.21; John Langton Gilks, 'The Medical Department and the Health Organization in Kenya, 1909-1933', The East African Medical Journal, 9, 1932-3, pp.340-54, p.342
} 
prominent Indians noticed this inadequacy of provision. A memorandum forwarded to London in 1922, by Nairobi-based politician Mr Varma, pointed out the extremely low number of doctors proportionate to the native population. He drew attention specifically to the unfair tax burden levied on African people in the light of the inadequacy of their health provision. A population of 80,000 Africans in one Province of Kenya was provided only two doctors, Mr Varma claimed-despite the fact that the hut and poll tax raised in the same region was $£ 600,000$. $^{66}$

By 1937 the composition of the medical staff had altered radically. The employment of European MOs had substantially increased, while the Indian subordinate staff had more than halved from their peak of 72 in 1919. Basic rural healthcare - which had been expanding steadily since the end of the First World War-instead came to be conducted by African dressers who had been introduced by the Medical Department as a result of adoption of a new policy in $1924 .{ }^{67}$ The number of African dressers went up to almost 700 in 1937 compared to a handful in $1925 .^{68}$ The policy which envisaged no explicit role for Indian doctors was summed up by the PMO as one of 'educating and encouraging African natives to play an ever increasing part in the work of the Department, that this policy has been successful because as teachers, and leaders, and guides, Government has been able ....an enthusiastic and highly trained European staff.... 69

But although to all intents and purposes they disappeared from official colonial office records, and although the policies to actively stimulate the recruitment of Indian doctors died a dramatic death after 1923 (Chapter Six), some Indian members of the Colonial medical department remained. ${ }^{70}$ As late as 1937 , about a third of the medical facilities in the native reserves were still under the charge of an Indian doctor. ${ }^{71}$ Although Indian names were no longer listed in the Annual Medical Reports (nor was any mention made of their roles), about

\footnotetext{
${ }^{66} \mathrm{BL} / \mathrm{IOR} / \mathrm{L} / \mathrm{E} / 7 / 1295$ 1921-1924, Industries and Overseas Department Papers, Notes of the Meeting between $\mathrm{Sec}$ of State for the Colonies and the Indian Delegation from Kenya, 4 May 1923, p. 16

${ }^{67}$ Annual Medical Report, 1924 p.1; John Iliffe, East African Doctors: a History of the Modern Profession, Cambridge University Press, 1998, p.24

${ }^{68}$ Annual Medical Report, 1936, p.7

${ }^{69}$ Annual Medical Report, 1933, p.1

${ }^{70}$ Annual Medical Report, 1932, p.2; Annual Medical Report, 1936, p.1 In both cases Paterson excluded Indian subordinate doctors from the count of medically qualified staff and made no references to their work.

${ }^{71}$ Annual Medical Report, 1937, p.7
} 
two dozen Indians continued to be noiselessly and unobtrusively employed by the

Government in the late 1930 s. $^{72}$

\section{Remit and Experiences:}

As so few records remain regarding the official employment of Indian Assistant and SubAssistant surgeons (no individual employment contracts could be found for example), it is difficult to estimate the average length of service. Record show that a few individuals, such as Anant Ram in 1909 were so disappointed with the reality of life in East Africa that they returned to India almost immediately upon arrival, but others indicate that individuals remained in Kenya for many years. ${ }^{73}$ In general, most Indian medical staff stayed for at least two years. Contracts were not issued for more than three years in length, however, again revealing a discrepancy between Indian and European Staff, longer service did occur, but was dependent upon the discretion of the PMO. Correspondingly the average length of service for an Indian doctor to work for the colonial medical department was lower than the average term in office experienced by European Medical Officers (eleven years). ${ }^{74}$ There were instances however where individuals stayed in service for many years. Sayyid Wilayat Shah from the Punjab, for example, joined the Colonial Medical Service in 1913 and stayed in government service for 32 years before setting up his own private practice in Nairobi. ${ }^{75}$

The lack of source material makes it similarly difficult to gain a picture of the typical experiences of Indian doctors. Similar to European doctors, most Indian doctors posted outside of the main townships conducted very independent professional lives, able to make their own decisions and often responsible, at a comparatively early stage of their careers, for

\footnotetext{
72 Annual Medical Report, 1937, p.5 lists 24 Asian Sub-Assistant Surgeons and 2 Asian Assistant Surgeons ${ }^{73}$ BL/IOR/L/MIL/7/14471 1907-1909 Collection 323/49 Memo: Medical Subordinates for Service in East Africa and Uganda, Government of India note, 17 June 1909; 10 September 1909. See also BL/IOR/L/MIL/7/2188 Government of India note 24 June 1897 (The case of Hospital Assistant R.F. Holder who refused to board the boat in Bombay when he learnt his family was refused free to passage to Mombasa) ${ }^{74}$ Anna Crozier, Practising Colonial Medicine: the Colonial Medical Service in East Africa, London, I.B. Tauris, 2007, p.112. (It should be noted that incomplete data does not allow for the computation of an average term of service for Indian subordinate doctors over the whole period. However, a comparison of information from the 1911 Blue Book with the information subsequently printed in the Official Gazettes of 25 February 1920 (p.138), 14 January 1930, 19 January 1932, p.59; 24 January 1939, p.114 indicates only 15\% of those serving in 1911 had been in the jobs for more than 10yrs. Similarly, about 20\% those serving in 1920 had had careers longer than 10 years; and about a third of those serving in 1930 and half of those serving in 1939.

${ }^{75}$ The Official Gazette, 24 January 1939; RHL/Papers Collected by H. Topiwala Related to Indian Doctors in Kenya, expected deposit date 2015, email communication between Harshad Topiwala and Anwar Sheikh (son of Sayyid Wilayat Shah) 5 November 2007
} 
thousands of patients. ${ }^{76}$ District medical reports from between 1915 and 1923 from Meru, between 1914 and 1922 in Malindi and 1921 in Kabarnet give an indication of the large levels of responsibility many Indian subordinate doctors had and contradict much of the European rhetoric in the press that Indians were insular and uncommitted to helping African communities. Disease prevalence is described in detail and the Indians in charge complained about the lack of resources and pitiful facilities. ${ }^{77}$ For instance, an Indian Assistant Surgeon was responsible for the hospital at Fort Hall during 1919 and a Sub-Assistant Surgeon was in charge of the Machakos hospital in the Ukamba reserve for several years before $1922 .{ }^{78}$ Although theoretically Indian subordinates were always under the supervision of the local $\mathrm{MO}$, in reality those in remote locations were only infrequently visited, in some instances only once a year. ${ }^{79}$

The range of medical challenges that any government employed doctor faced in East Africa was formidable. Indians were regarded as having an advantage however, because of their knowledge of tropical diseases, gleaned from their first-hand experiences in India. As one scholarly assessment of the white community of colonial Kenya pointed out: 'The doctors were reliant on Indian Sub-Assistant surgeons, frequently very skilled and superior to qualified new recruits from Britain in their knowledge of tropical ailments. ${ }^{80}$ This predisposition was fortunate as no evidence can be found of any specific training being given to newly recruited Indian doctors in terms of adapting them to the East African disease environment. It is likely that Indians were employed and thrown into their duties at the deep end with no induction or training. ${ }^{81}$

\footnotetext{
${ }^{76}$ RHL/MSS.Afr.s. 702 Robert Arthur Welsford Procter, 'Random Reminiscences, Mainly Surgical' [no date]; Anna Crozier, Practising Colonial Medicine: the Colonial Medical Service in East Africa, London, I.B. Tauris, 2007, pp.87-88

${ }^{77}$ Syracuse University (SU), Kenya National Archive Records (KNA), Mircrofilm Number 2801, Annual and Quarterly Reports (Provincial and District) Reel 15: Provincial Medical Report, E.B. Horne, Meru, 1915 and 1916; Provincial Medical Report, Abdulla Khan, Meru, 1918-20; Provincial Medical Report, Ali Baksh, Meru, 1922; Reel 21: Provincial Medical Report, Gokul Chand, Kabarnet, 1921; Reel 56: Provincial Medical Report Maula Buksh, Kilifi, 1918-19; Reel 59: Provincial Medical Reports, Maula Buksh, Malindi, 1918-19

${ }^{78}$ A.N. Nyss, Annual Medical Report, 1919,p.14; Annual Medical Report, 1921, p.22

${ }^{79} \mathrm{SU} / \mathrm{KNA} /$ Mircrofilm Number 2801, Annual and Quarterly Reports (Provincial and District), Reel 21: Provincial Medical Report, Gokul Chand, Kabarnet, 1921, Provincial and District Reports, Gokul Chand, Kabarnet Medical Report, p.30; See also WL/CMAC/PP/HCT/A5 Elizabeth Bray, Hugh Trowell: Pioneer Nutritionist, unpublished biography, London 1988

${ }^{80}$ Christine Stephanie Nicholls, Red Strangers: The White Tribe of Kenya, London, Timewell Press, 2005, p.209

${ }^{81}$ To be fair European Medical Officers were also given very little on the job training: typically just a few days orientation in either Nairobi or Mombasa. They usually were required to have undertaken the Diploma of Tropical Medicine and Hygiene however at either the London or Liverpool schools. See Anna Crozier, Practising Colonial Medicine: the Colonial Medical Service in East Africa, London, I.B. Tauris, 2007, p.26
} 
Similar to what we know about the lives of European Medical Officers, the accounts that remain attest to the fact that the job was arduous. Not only was disease rife, but facilities were poor and too patients numerous to give individual care and attention. One common feature of the Indian colonial medical experience was that Indian subordinates were switched between stations as needs arose with little apparent concern for maintaining a continuity of personnel locally. There is evidence, for example, that Sayyid Wilayat Shah was in nine different stations throughout his career-Kisumu, Kericho, Fort Hall, Nyeri, Kitui, Nakuru, Malindi, Kisumu (again) and Kajiado. ${ }^{82}$ Similarly, Sub-Assistant Surgeon A. N. Bowry and his family were moved around a number of distant dispensaries throughout his career during the 1930s. His inconvenience of having to work at Garissa, Lodwar, Marsabit, Wajir, Meru, Lamu, Nanyuki and Thika as well as Nairobi actually earned him the rare privilege of a salary bonus for the hardships he had to endure. These were adventures, he recounted, that once even literally saw him and his family fleeing from lions. ${ }^{83}$

Furthermore, the Indian Subordinate, however well qualified, was not encouraged to participate in research. This was a 'civilised' pedagogical pursuit considered only appropriate for Europeans. Restrictions were tangible. If an Indian subordinate wanted to publish their research findings in the most important local medical journal, the Kenya Medical Journal (after 1932, East African Medical Journal) they had to be accepted by the editor, which in the racially exclusionist climate of the time, was not always easy. ${ }^{84}$ Nevertheless, although stateemployed Indian doctors seem to have been more inclined to secure private patients to supplement their income in his spare time rather than pursue research, it seems that a substantial number nevertheless were regularly research active. Between 1922 and 1940 fifteen different Indian medical department colleagues contributed to the Kenya Medical Journal reporting on topics as varied as pellagra, pneumonia, surgical methods and memory loss, although it should be noted that articles tended to be shorter than those contributed by Europeans, or came in the form of notes and comments. ${ }^{85}$ Some individuals undertook large

\footnotetext{
${ }^{82}$ The Official Gazette, 24 January 1939; RHL/Papers Collected by H. Topiwala Related to Indian Doctors in Kenya, expected deposit date 2015, email communication between Harshad Topiwala and Anwar Sheikh (son of Sayyid Wilayat Shah) 5 November 2007

${ }^{83}$ Cynthia Salvadori, We Came in Dhows, Nairobi, Paperchase Kenya Ltd, 1996 Vol. 3, p.90 [Contribution by Usha Dupta].

${ }^{84}$ Not least as the editor of the EAMJ between 1922-28 was Christopher Wilson, who held explicitly white supremacist view. See C.J. Wilson, Before The Dawn in Kenya, Nairobi, The English Press, 1952; C.J. Wilson, Kenya Warning: The Challenge to White Supremacy in Our British Colony, Nairobi, The English Press, 1954

${ }^{85}$ It might be possible to speculate here whether Indian researchers were denied the same journal space as Europeans through editorial decisions however.
} 
surveys of their local African communities and were committed to the improvement of standards of care and the expansion of knowledge about African diseases and their mitigating factors. As with most European research, most of this published research was related to the treatment of African patients. Although this is in itself not surprising, it nevertheless forcibly contradicts one of the dominant stereotypes propagated against Indian medical practitioners: namely that they were uninterested in African patients and therefore fundamentally unsuited to medical roles of responsibility in the African region. ${ }^{86}$

Other evidence also seems to contradict this idea, chiefly propagated by members of the settler community, that Indians were somehow disengaged with medical research concerning the local African community. For example the 1913 Annual Medical Report describes in significant details the anti-plague campaigns of three Indian doctors: A.N. Nyss, K.H. Bhatt and Murari Lal. ${ }^{87}$ Another article from 1927 by Assistant Surgeon T.D. Nair, described his extensive yaws eradication campaign along the Tana river. ${ }^{88}$ An additional medical report authored by Minoo Dasturin reveals in vivid detail his substantial initiatives to improve public health provision in the Baringo district of Kenya ${ }^{89}$ Although ultimately the European management dictated what the public health or disease eradication programmes would be, the descriptions of the social conditions described in these reports (along with the accounts of the responsibilities routinely managed) confirmed that subordinate doctors in practice acted independently of their European seniors, carrying out large disease surveys and widespread public health campaigns. In the 1913 Plague survey, for example, it was acknowledged that Indian subordinates were responsible for attending to all reported cases of plague, performing inoculations to all those without a certificate of inoculation and also were responsible for making the decision to close individual dwellings if deemed necessary. Additionally subordinates were called upon to take trips out of the town to investigate rural outbreaks of plague and, where necessary, set up camps. Murari Lal was to conduct precisely this sort of rural investigation in 1913. His resulting report is particularly revealing of his personal pride over the success of the plague inoculation campaign. He was happy to declare that under his supervision 'Each and every person of village has been inoculated'. 90 Assistant Surgeon Nyss similarly described in detail his experiences of plague control at the village of Tsanganzani.

\footnotetext{
${ }^{86}$ AMR 1923, p.1; BMA/B/162/1/9 Dominions Committee Documents, Session 1921-1922, Meeting 30 June 1922, p.1, hh

${ }^{87}$ A.N. Nyss, AMR, 1913, pp.77-80.

${ }^{88}$ T.D. Nair, 'A Tana River Yaws Campaign', Kenya and East Africa Medical Journal, 4.7, 1927-28, pp.201-7

${ }^{89}$ Cynthia Salvadori, We Came in Dhows, Nairobi, Paperchase Kenya Ltd, 1996, Vol. III, p.140

${ }^{90}$ AMR, 1913, p.77
} 
His notes indicate that he was meticulous in gathering evidence on the differing levels of infection between peoples of different tribal ethnicity, particularly mapping differentials in incidence between the Wadigo and the Kavirondo. The way his report was structured provides a clear indication that Nyss hoped his findings would be useful as part of broader medical research over East African plague. His efforts were appreciated by the colonial medical department and faith in his abilities was confirmed when he was put in charge of the important Fort Hall Hospital in 1919. ${ }^{91}$

Although not a majority a number of Indian government doctors clearly saw themselves as full engaged, research-active medical practitioners, rather than general unscientific dogs bodies who only helped out in subordinate medical roles. For example, a fascinating account of a hundred day long expedition along the Tana River in second half of the 1920s conducted by Assistant Surgeon Nair provides insights into the way a large yaws eradication campaign in what was regarded as the 'most unhealthy and cheerless part of the colony' was undertaken. ${ }^{92}$ In the course of this campaign Nair reported to have personally treated over 3,000 patients with the help of just six African dressers. The level of detail in Nair's report also attests to his serious scientific interest in the subject. Nair provided extensive research data on the results he achieved from the microscopic examination of smears from typical ulcerations and stressed the importance of relating his local findings to findings in other parts of East Africa. ${ }^{93}$

Finally, the medical report for Baringo district, authored by Parsi Minoo Dastur (served between 1932 and 1941), provides another example of the professional attitudes of an Indian doctor employed by the Government Medical Department in mid 1930s. ${ }^{94}$ In a lucid, wideranging report Dastur described the geography, population, social conditions, education, sanitation and the medical services provided in the region. Drawing on his experiences in charge of the small twenty-bed hospital at Kabarnet and four dispensaries located at Marigat, Emining, Nginyang and Mukutan Dastur wrote with considerable sensitivity and professionalism about the medical problems of the different peoples within his station. As an

\footnotetext{
${ }^{91}$ AMR, 1919, p.14

${ }^{92}$ T.D. Nair, ‘A Tana River Yaws Campaign', Kenya and East Africa Medical Journal, 4.7, 1927-28, pp.201-7, p. 201

93 T.D. Nair, 'A Tana River Yaws Campaign', Kenya and East Africa Medical Journal, 4.7, 1927-28, pp.201-7, pp. $205-7$

${ }_{94}$ Cynthia Salvadori, We Came in Dhows, Nairobi, Paperchase Kenya Ltd, 1996, Vol. III, pp.140-1 [A summary of the 29 page medical report from Dastur while he was in Baringo in 1935]
} 
active proponent of improved public health education, he insightfully recommended that education programmes should be undertaken through regular informal meetings with the community (called barazas) as the 'real work lies in the Reserve proper'. 95

Insights into the professional activities of Indian doctors can also be gained through reading the district level reports submitted (via the District Officer) to the central medical department each year for the consideration of the PMO for possible reporting in the Annual Medical Report. What is particularly indicative of attitudes during this period is that although these local reports by Indian doctors were submitted on time, they were rarely used in the final medical reports supervised by the PMO. ${ }^{96}$

Lastly, there is no need to conjure up too romantic a view. It is clear that not all Indian doctors employed by the medical department were upstanding and honest. Some individuals were found guilty of criminal activities, such as the doctor who as sentenced to a three-month prison sentence after he was found guilty of possession of cocaine and theft of government property. ${ }^{97}$ Another was found to have committed perjury and an accessory to a murder in $1931 .^{98}$ Needless to say, in the racially prejudiced world of colonial Kenya, the European press took up such reports with barely-hidden glee.

\section{Social Standing}

Before the 1920s individuals working in East Africa, India and the UK regularly praised the quality of Indian staff. E.B. Horne who was the District Officer in Meru, for example, was immensely impressed by the performance of Abdulla Khan who commenced work in Meru in 1915, describing his 'relations with the natives' as 'excellent'. Horne further commented that because of Khan's professional efforts and good personal relations there had been a substantive increase in patient consultations under his tenure. ${ }^{99}$ Similarly, a report issued in 1921 concerning the remote Kabarnet station which was considered to have 'deplorable'

\footnotetext{
${ }_{95}$ Cynthia Salvadori, We Came in Dhows, Nairobi, Paperchase Kenya Ltd, 1996, Vol. III, pp.141

${ }^{96}$ As evidenced by the absence of reports by Maula Baksh, Abdulla Khan, Gopal Chand and Ali Baksh in the ANNUAL MEDICAL REPORTs though they submitted reports regularly at district level.

97 'The Indian and Cocaine', The East African Standard, 18 April 1931, p.32

98 'Echo of the Murder at Meru', The East African Standard, 18 July 1931, p.42

${ }^{99}$ SU/KNA Mircrofilm Number 2801, Annual and Quarterly Reports (Provincial and District) Reel 15: Provincial Medical Report, E.B. Horne, Meru, 1915 and 1916; Provincial Medical Report, Abdulla Khan, Meru, 1918-20; Provincial Medical Report, Ali Baksh, Meru, 1922; Reel 21: Provincial Medical Report, Gokul Chand, Kabarnet, 1921; Reel 56: Provincial Medical Report Maula Buksh, Kilifi, 1918-19; Reel 59: Provincial Medical Reports, Maula Buksh, Malindi, 1918-19
} 
facilities and to be 'notoriously unhealthy' is fully appreciative of the changes that occurred under the Indian doctor's charge. ${ }^{100}$ Six months after Gokul Chand's appointment to the station, the District Commissioner was happy to report that 'his work has been eminently satisfactory, the sanitation of the station is looked after by him with great care'. ${ }^{101}$

In his published reminiscences of 1928 'The Rise of the Colonial Medical Service' former PMO, Arthur Milne also extoled the contribution of Indian doctors and Goan clerks in glowing terms, describing them as 'the two main-springs which have kept the wheels of the department turning'. ${ }^{102}$ He singled out a number of individuals for their gallantry and dedication to the establishment of colonial medicine in the region, and included Assistant Surgeon de Cruz as one of 'those never- to- be forgotten comrades who laid down their lives in the building up of these colonies'. ${ }^{103}$ Other European Medical Officers provided similar positive testaments of the Indian medical staff. R.S.F. Hennessey, made particular note of the vital role of the Indian doctors in running of the hospitals and their importance in undertaking much of the routine surgery. ${ }^{104}$ Another senior European MO, Peter Clearkin, who worked for sometime at Kisumu Hospital, described some of the Assistant Surgeons he worked with as 'very good indeed', making specific reference to the outstanding efforts of one individual, Kartar Singh. ${ }^{105}$ Norman Jewell was appreciative enough of the services of two Sub-Assistant Surgeons he worked with (Abdul Kadir and Zorawar Singh) to make specific reference to them in glowing terms within his private autobiography. ${ }^{106}$ Indeed, the praise of Indian doctors in matters relating to tropical diseases was sometimes extended even to the point of controversy. For example, even as early as 1861, British member of the House of Lords, Lord Ellenborough reported after a visit to India, that he felt Indian doctors to be superior to

\footnotetext{
${ }^{100}$ SU/KNA Mircrofilm Number 2801, Annual and Quarterly Reports (Provincial and District) Reel 15: Provincial Medical Report, E.B. Horne, Meru, 1915 and 1916; Provincial Medical Report, Abdulla Khan, Meru, 1918-20; Provincial Medical Report, Ali Baksh, Meru, 1922; Reel 21: Provincial Medical Report, Gokul Chand, Kabarnet, 1921; Reel 56: Provincial Medical Report Maula Buksh, Kilifi, 1918-19; Reel 59: Provincial Medical Reports, Maula Buksh, Malindi, 1918-19

${ }^{101}$ SU/KNA Mircrofilm Number 2801, Annual and Quarterly Reports (Provincial and District) Reel 21: Provincial Medical Report, Gokul Chand, Kabarnet, 1921; See in the same report comments of District Commisioner Bamber on the performance of Gokul Chand, p.1

${ }^{102}$ Arthur Dawson Milne, 'The Rise of the Colonial Medical Service', Kenya and East African Medical Journal, $5,1928-9$, pp. $50-8$, p. 58

${ }^{103}$ Arthur Dawson Milne, 'The Rise of the Colonial Medical Service', Kenya and East African Medical Journal, $5,1928-9$, pp. $50-8$, p.58

${ }^{104}$ RHL/MSS.Afr.s. 1872/75, Robert Samuel Hennessey, Memorandum on Experiences in the Colonial Medical Service in Uganda, 1929-55

${ }^{105}$ RHL/MSS.r.4.I, P.A. Clearkin, Rambling and Recollections of a Colonial Doctor, 1913-58, unpublished manuscript, p. 126

${ }^{106}$ Norman Parsons Jewell, [ed. Tony Jewell], On Call, Privately Published, forthcoming, 2015 [Chapter 4; Chapter 11, not yet paginated]
} 
Europeans for medical work in the tropics due to their first-hand knowledge of local diseases. This claim enraged some British doctors who responded enthusiastically in the pages of the Lancet. $^{107}$

Despite positive, first hand descriptions, the one element that remained a consistently controversial point in the debates over Indian doctors concerned the quality of the medical training offered in the Indian medical schools and colleges. ${ }^{108}$ Most British officials and academics generally considered not only the shorter 'subordinate' training but also the GMC approved courses offered by colleges to be inferior to that available in the West. So much so, that the poorer quality was frequently cited as sufficient explanation for appointing Indian doctors on a lower grade than their European counterparts. Leading these criticisms was the BMA, which argued that training within Indian medical schools varied drastically, was not subject to regular audit inspections and could not provide a reliable equivalent standard to British medical degrees. While the BMA conceded that some institutions provided a good medical education, it firmly maintained that others were of a 'deplorably bad standard'. ${ }^{109}$ Overall the BMA lumped doctors with the GMC approved degree qualifications from Universities and those with the truncated training from Medical Schools in its judgement of Indian doctors: 'his standards are still far from being of his British brother'. ${ }^{110}$ Such opinion had long been held by leading members of the IMS, such as Sir G Gifford, who in 1924 claimed that throughout India dispensaries were staffed by subordinate doctors who were 'inferior and imperfectly trained' having graduated from medical schools in India which were 'shamefully inefficient'. ${ }^{111}$ In a display of barely concealed prejudice Gifford argued that improvements in colonial health could only be made by the 'instrumentality of European medical men.' He poured scorn on the recommendation of Lee Commission into Indian Medical Service of 1924, which would lead to Europeans serving as 'an equal with Indians

\footnotetext{
107 'Lord Ellenborough and the Indian Medical Service', The Lancet, 14 December 1861, p.581

108 'Indian Medical Degrees: The General Medical Council and Indian Qualifications: History of a Ten Year Controversy', British Medical Journal, 15 March 1930, pp.505-11

109 'The Framework of Medicine in India', The Lancet, 16 October 1937, pp.933-5, p.934

${ }^{110}$ BL/IOR L/MIL/7/14157 'Rules Governing Admission -BMA Memorandum on the Present Position and Future Prospects of the Indian Medical Service', 20 February 1914, p.1; also see Cd.7900, HMSO,1915 Minutes of the evidence relating to Medical Services, p188, R.W. Lyon, Surgeon General ' I consider the maintenance of a preponderance of European element essential....'

111 'The Future of Medicine in India: Sir Gerald Gifford's Address' British Medical Journal, 22 November 1924, p.966; Roger Jeffery, 'Recognizing India's Doctors: The Institutionalization of Medical dependency, 1918-1939', Modern Asian Studies, 13.2, 1979, pp.301-26, p.324
} 
who would certainly be in most cases not as well qualified'. ${ }^{112}$ As Roger Jeffery has shown, it was to take some time and persuasion for Indian doctors (registered, not licenced) to have their degrees recognised as being the same level as those gained in Western based university locations. $^{113}$

The Kenya branch of the BMA echoed many of these views, often contradicting the positive comments that emanated from individuals within the medical department. In one of its memoranda to London the Kenya Branch of the BMA's close alignment to the prevailing European sentiments of racial superiority was made explicit:

A specific question having been asked by the Commission as to the efficiency of Indian sub-assistant surgeons, the Branch wishes to express the opinion that though they may fulfil a useful function when working under the supervision of medical officers, yet, owing to their attitude towards the African they are as a rule unsatisfactory for independent medical work amongst natives. At the time of retrenchment the establishment of sub assistant surgeons was greatly reduced. This was a step in the right direction and the Branch considers that the eventual replacement of Asiatics is desirable. The replacement of an Asiatic subassistant surgeon in charge of an outstation by a medical officer entails additional expense yet the increase in value of the public health service rendered is out of all proportion to the increase in cost. ${ }^{114}$

This highly negative assessment of the suitability of Indian doctors fitted with the new mood of the mid 1920s, but nevertheless contradicted many earlier testimonials of Indian subordinate work and much of the flattering historical evidence found within regional and national medical reports.

\footnotetext{
112 'The Future of Medicine in India: Sir Gerald Gifford's Address' British Medical Journal, 22 November 1924, p.966

${ }^{113}$ Roger Jeffery, 'Recognizing India's Doctors: The Institutionalization of Medical Dependency, 1918-39', Modern Asian Studies, 13.2, 1979, pp.301-26, p.307; Roger Jeffery, 'Doctors and Congress: The Role of Medical Men and Medical Politics in Indian Nationalism', in Mike Shepperdson and Colin Simmons (eds.), The Indian National Congress and the Political Economy of India, 1885-1985, Aldershot, Brookfield, USA, Avebury, 1988, pp.160-73, p.161

${ }_{114}$ BMA/B/162/1/12 Dominions Committee Documents, Session 1924-5, 6 March 1925, p.3; Memorandum on Medical and Sanitary Services from Kenya BMA Branch, 5 March 1925, p.3
} 
Yet, as late as 1955 a memo by the Director of Medical Services, in a move to recruit GMC qualified Indian doctors to fill Medical Officer level vacancies decisively reported that, despite the economies that could be made, Indian doctors should not be 'selected for appointment as Medical Officers by the Secretary of State'. ${ }^{115}$ In forty years attitudes towards Indian doctors seemed to have remained fundamentally unchanged.

Although accounts left by Indian members of the medical service are few and evidence has had to be pulled together from disparate sources, it has nevertheless still been possible to build up a picture of the conditions and experiences of Indian doctors in the Colonial Medical Service. Indian doctors, although employed on less favourable contractual terms - and typically posted to the less popular remote stations - nevertheless were undoubtedly an extremely valuable part of the health service infrastructure, easily outnumbering European doctors. Despite operating in a climate that routinely discriminated against them, several of them showed themselves to be active researchers, ambitious in their professional scope and intentions. They often worked independently and in positions of considerable responsibility. Many led campaigns against specific diseases, conducted large-scale disease surveys or managed key hospitals and their staff. Despite the increasingly hardening racial attitudes within East Africa, to all intents and purposes, before 1922, the situation of relying on Indian doctors within the government medical service looked to be one that was unlikely to change.

\footnotetext{
${ }^{115} \mathrm{KNA} / \mathrm{MOH} /$ File 1/716, Memo from Director of Medical Services, 'Appointment of Asian Doctors', 11 January 1955
} 